\title{
GASTRIC MYOELECTRICAL ACTIVITY IN NEONATES OF DIFFERENT GESTATIONAL AGES BY MEANS OF ELECTROGASTROGRAPHY
}

\author{
Alexander Roberto Precioso ${ }^{1}$, Gilberto R. Pereira ${ }^{2}$ and Flávio Adolfo Costa Vaz ${ }^{3}$
}

PRECIOSO AR et al. - Gastric myoelectrical activity in neonates of different gestational ages by means of electrogastrography.

Rev. Hosp. Clín. Fac. Med. S. Paulo 58(2):81-90, 2002.

PURPOSE: to describe the patterns of the gastric myoelectrical activity, pre-and postprandially, in clinically stable neonates of different gestational ages, during their first two weeks of life by means of Electrogastrography.

PATIENTS AND METHODS: Electrogastrography was recorded in forty-five clinically stable neonates of different gestational ages (group I: 15 neonates of > 37 weeks, group II: 15 premature neonates of 32-37 weeks; Group III: 15 premature neonates of 28-31 weeks) receiving intermittent enteral feedings during their first two weeks of life. Electrogastrography recordings were performed for 1 hour pre-and postprandially. The Electrogastrography signal was recorded using the portable MicroDigitrapper Electrogastrography recording device and after motion artifacts were deleted, the remaining Electrogastrography data were submitted to quantitative analysis based on the "Running Spectrum Analysis".

RESULTS: The percentages of normogastria, pre-and postprandially were greater than the percentages of gastric dysrythmias in all three studied groups. Furthermore, all neonates had the mean values of the Electrogastrography dominant frequency predominantly within the normogastria range, in both periods analyzed. There were no significant differences in the relative change of the Electrogastrography dominant power among the groups.

CONCLUSION: This study demonstrates that the Electrogastrography patterns are similar between premature and full term neonates during the pre-and postprandial periods. The results of this study also indicate that the gastric myoelectrical activity in premature and full term neonates is immature, as compared to that described for older neonates, children and adults.

DESCRIPTORS: Electrogastrography. Gastric myoelectrical activity. Neonates. Different gestational ages. Preand postprandial periods.

\section{INTRODUCTION}

The need to provide the newborn with adequate nutrition in order to ensure survival has long been recognized $^{1}$. The use of enteral nutrition in very-low-birth-weight neonates, however, is associated with a significant morbidity related to immaturity of gastrointestinal motor function ${ }^{2,3}$.

A renewed interest in using early enteral nutrition in neonates has developed based on the morbidity associated with the use of parenteral nutrition and its expense. In order to achieve successful enteral feedings in premature and full term neonates, investigators have tried to better understand the developmental patterns of gastrointestinal motor activity ${ }^{4-21}$.

Despite several gastrointestinal

From the ${ }^{1,3}$ Pediatric Department, Division of Neonatology and the ${ }^{1}$ Experimental Unit, Children's Institute, Hospital das Clinicas, Faculty of Medicine, University of Sao Paulo and the ${ }^{2}$ Division of Neonatology, Children's Hospital of Philadelphia - PA, EUA. Received for publication on July 03, 2002. motility studies have been made in adults during the last decades, the knowledge derived from systematic scientific observation in this area in neonates remains scarce. To a large extent, this is due to the fact that invasive and unpleasant investigations are required to study the contractile activity of the gastrointestinal tract via the lumen. In neonates and in children, such invasive investigations are less acceptable to patients and consequently put severe limitations on systematic studies. 
Due to its non-invasive quality the Electrogastrography (EGG) technique has received more and more attention among investigators and clinicians as an attractive method for physiological and pathophysiological studies of the gastric myoelectrical activity by electrodes placed on the abdomen. The surface recording obtained with the use of electrogastrographic technique has been called the electrogastrogram ${ }^{22-25}$.

During the past decades the EGG has been performed extensively in adult population. It has been used to study patients with abnormalities in gastric function such as gastroparesis ${ }^{26,27}$ and functional dyspepsia and delayed gastric emptying ${ }^{28}$. In addition, the EGG has been used to evaluate the effects of compositions of feedings, gut hormones and prokinetic agents on gastric motility ${ }^{29-32}$.

The use of the EGG technique in neonates and children began in the late 1980s. It has been basically used to investigate the development of gastric motor activity in neonates and children $^{33-38}$ and to describe the gastric myoelectrical activity in different diseases as idiopathic intestinal pseudoobstruction $^{39}$, non-ulcer dyspepsia ${ }^{40}$, disorders of the central nervous system $^{41}$, and anorexia nervosa ${ }^{42}$. However, there is a lack of EGG data among neonates of different gestational ages. Therefore, the objective of this study was to describe the patterns of the gastric myoelectrical activity, pre-and postprandially, in clinically stable neonates of different gestational ages, during their first two weeks of life by means of EGG.

\section{PATIENTS AND METHODS}

\section{Subjects}

Forty-five clinically stable neonates of different gestational ages receiving intermittent enteral feedings during their first two weeks of life were assigned into 3 study groups: Group I: 15 full term neonates of $>37$ weeks; Group II: 15 premature neonates of 3237 weeks; Group III: 15 premature neonates of 28-31 weeks. The gestational age used for enrollment into study groups was based on maternal dates, confirmed by prenatal ultrasonographic assessment (if available) and by physical exam using the method of Ballard ${ }^{43}$. In case of a discrepancy of less than 2 weeks between maternal dates and other methods, the maternal dates were used. In case of a discrepancy greater than 2 weeks, the average value between ultrasonographic and clinical assessment was used.

All neonates were enrolled in this study based on inclusion and exclusion criteria. Inclusion criteria: clinically stable premature and full term neonates ready to receive intermittent enteral feedings during their first two weeks of life. Exclusion criteria: inherited/congenital anomalies, intrauterine growth retardation, medical instability with contraindications to enteral feedings, respiratory distress requiring mechanical ventilation, muscle paralysis, gastrointestinal, hepatic, metabolic or infectious diseases, conditions requiring the use of drugs known to affect EGG signals and gastrointestinal motility such as: paralytic agents (pancuronium); opioids (morphine, enkephalin); hormones (secretin, insulin, prostaglandins); prokinetic agents (cisapride, metoclopramide); and antibiotics (erythromycin). Neonates with hyperbilirubinemia who require phototherapy were also excluded based on the necessity to swaddle the infant during the study.

This scientific investigation was approved by the Institutional Review Board at the Children's Hospital of Philadelphia and the Hospital of the University of Pennsylvania prior to infant's enrollment into the study. Signed written consent was obtained from the neonates' parents or guardians before the study. National Institute of Health (USA) guidelines for inclusion of patients using unbiased selection according to gender and ethnicity were followed.

\section{Preparation of the patient for an Electrogastrography study}

Gastric myoelectrical activity in each subject was measured using the Electrogastrography technique during the pre-and postprandial periods. Before the electrodes were attached, the abdominal skin at the recording sites was gently cleaned using sandy skinpreparation paste to reduce the impedance $^{36,43}$. Three pediatric disposable silver-silver chloride electrodes filled with EGG redux (Signa creme-conducter electrode creme) gel were placed on the abdominal skin accordng to Liang $^{36}$ and Chen's studies ${ }^{38}$. One active electrode was placed at the midpoint between the xiphoid and the umbilicus; a second active electrode was placed at $3 \mathrm{~cm}$ to the left and $3 \mathrm{~cm}$ above this point; and a reference electrode was placed in the lower quadrant close to the left costal margin. The two activeepigastric electrodes were connected to yield a bipolar EGG signal, while the other electrode was used as a reference.

The EGG signal was recorded using the portable MicroDigitrapper EGG recording device (Synectics Medical, Irving, TX), with low and high cutoff frequencies of 1 and 18 cpm, respectively ${ }^{45}$. The EGG signal was digitized with a sampling frequency of $4 \mathrm{~Hz}^{45}$. The EGG recording device was operated by a new $9-\mathrm{V}$ battery in each study. The EGG recording device was brought to the neonatal unit in which the infant was located and all neonates were studied at their bedside.

\section{Experimental study}


All infants were fasted (for 3 hours) before the study and received either formula or breastfeeding. An 1-hour EGG recording time, before and after feeding were obtained. All were studied in the supine position but lying slightly on their left side on a bed with the head elevated to a $30^{\circ}$ angle. They were also gently swaddled to reduce the occurrence of motion artifacts on the EGG signal.

\section{Electrogastrography data analysis}

At the end of each study, the EGG recording device was connected to a personal computer (Hewlett-Packard 9826) and the EGG data were uploaded in the Clinical Motility Center at the Hospital of University of Pennsylvania. Before quantitative and statistical analysis, the EGG recording was first displayed on the computer screen and the portions contaminated by motion artifacts were deleted. Motion artifacts were characterized by an abrupt increase in amplitude and usually reached maximum values of the digitization. All data within one hour before the meal were considered as preprandial and all data within 1 hour after the meal were considered as postprandial. After motion artifacts were deleted, the remaining "cleaned" EGG data were submitted to quantitative analysis performed by the "Electrogastrogram Software for EGG analysis" (Synectics Medical-Gastrosoft, version $6.30,1995)$, which is based on the "Running Spectrum Analysis".

The pattern of the EGG was characterized by several quantitative parameters, including: a) percentage of normogastria (or percentage of 2.4 to 3.7-cpm gastric slow wave) defined as the percentage of time in which a rhythmic gastric myoelectrical activity of 2.4 to $3.7-\mathrm{cpm}$ is present over the entire observation period ${ }^{46}$; b) percentage of bradygastria defined as the percentage of time in which an abnor- mally slow gastric myoelectrical activity of 0.5 to 2.4 -cpm range is present over the entire observation period ${ }^{46} ; \mathrm{c}$ ) percentage of tachygastria defined as the percentage of time in which an abnormally fast gastric myoelectrical activity of 3.7 to $9.9-\mathrm{cpm}$ is present over the entire observation period ${ }^{46} ; d$ ) EGG dominant frequency defined as the frequency that the power of the EGG signal has at its peak value in the range of 0.5 to $9.0-\mathrm{cpm}^{46}$; and e) EGG dominant power (Relative change of the EGG dominant power). The EGG dominant power is defined as the power at the dominant frequency and it reflects the amplitude and regularity of gastric low wave ${ }^{46}$. The relative change of the EGG dominant power is defined as the ratio of postprandial and preprandial powers of the EGG dominant frequency ${ }^{47,48}$.

\section{Statistical analyses}

Analysis of variance (ANOVA) was used to assess the difference in the EGG data among patients from the 3 gestational age groups. ANOVA was also used to assess the difference in the "EGG difference score" (preprandial minus postprandial values) regarding to all EGG parameters analyzed among patients from the 3 gestational age groups. Paired t-test was applied to study the difference between the preprandial and postprandial EGG data for each of the gestational age groups. All EGG data in this study is presented as "Means \pm Standard Error of Mean (SEM)". Statistical significance was assigned for $\mathrm{p}$ value of less than 0.01 .

\section{RESULTS}

Group I of subjects was composed of 15 clinically stable full term neonates. The Apgar scores at one and at five minutes of life were (Mean \pm SEM) $8.3 \pm 0.2$ and $8.9 \pm 0.1$, re- spectively. The gestational age at birth and at the time of the study were: (Mean \pm SEM) 39.1 \pm 0.3 weeks (range: 37 to $405 / 7$ weeks) and $39.5 \pm 0.4$ weeks (range: 37 2/7 to $413 / 7$ weeks), respectively. The weight at birth and at the time of the study were (Mean \pm SEM) $3.3 \pm 0.2 \mathrm{~kg}$ (range: 2 . to $4.50 \mathrm{~kg}$ ) and $3.3 \pm 0.2 \mathrm{~kg}$ (range: 2.36 to $4.53 \mathrm{~kg}$ ). Three neonates $(20 \%)$ were White and 12 (80\%) were Afro-Americans. Four neonates $(26.7 \%)$ were male and $11(73.3 \%)$ were female. Ten neonates $(66.7 \%)$ were appropriate for gestational age and $5(33.3 \%)$ were large for gestational age. Six neonates $(40 \%)$ were on breastfeeding and nine $(60 \%)$ were on formula (Similac-20 or Enfamil-20). Based on the milk volume that could be measured, the volume, the amounts of calories, protein, carbohydrate, and fat per kilogram body weight per day among the full term neonates were (Mean \pm SEM): Volume: $81.5 \pm 11.5 \mathrm{ml} / \mathrm{kg} /$ day; Calories: $55.2 \pm 7.8 \mathrm{kcal} / \mathrm{kg} /$ day; Protein: $1.1 \pm 0.2$ $\mathrm{g} / \mathrm{kg} /$ day; Carbohydrate: $5.9 \pm 0.8 \mathrm{~g} /$ kg/day; Fat: $2.9 \pm 0.4 \mathrm{~g} / \mathrm{kg} /$ day. The EGG preprandial study period recorded and analyzed among these neonates were: (Mean \pm SEM) 56.7 \pm 3.2 and $38.3 \pm 2.3$ minutes, respectively. The EGG postprandial study period recorded and analyzed in this group was (Mean \pm SEM) 56.3 \pm 3.9 minutes and $37.2 \pm 2.7$ minutes, respectively. The time that the EGG study was performed in this group was (Mean \pm SEM) $3.3 \pm 0.8$ days of life.

Group II of subjects was composed of 15 clinically stable premature neonates (32-37 weeks). The Apgar scores at one and five minutes of life were (Mean \pm SEM) 7.3 \pm 0.6 and $8.8 \pm 0.1$, respectively. The gestational age at birth and at the time of the study were (Mean \pm SEM) 34.5 \pm 0.3 weeks (range: $331 / 7$ to 36 weeks) and $35.1 \pm 0.3$ weeks (range: $335 / 7$ to 36 $5 / 7$ weeks), respectively. The weight at birth and at the time of the study 
were (Mean \pm SEM) $2.14 \pm 0.1 \mathrm{~kg}$ (range: 1.45 to $2.90 \mathrm{~kg}$ ) and $2.04 \pm 0.1 \mathrm{~kg}$ (range: 1.40 to $2.76 \mathrm{~kg}$ ), respectively. Five neonates $(33.3 \%)$ were White, 9 $(60 \%)$ were Afro-Americans, and 1 $(6.7 \%)$ was Hispanic. Six neonates $(40 \%)$ were male and $9(60 \%)$ were female. Among these premature neonates 14 were appropriate for gestational age and 1 was large for gestational age. Thirteen neonates $(86.7 \%)$ were on formula (Enfamil Premature Formula-20, or Enfamil-20, or Similac Neocare-22, or Similac Special care, or Similac 20) and two $(13.3 \%)$ were on breastfeeding. Based on the milk volume that could be measured the volume, the amount of calories, protein, carbohydrate, and fat per kilogram body weight per day among these premature neonates were $(M e a n \pm S E M)$ : Volume: $116.8 \pm 15.2 \mathrm{ml} / \mathrm{kg} / \mathrm{day} ;$ Calories: $78.97 \pm 10.57 \mathrm{kcal} / \mathrm{kg} / \mathrm{day}$; Protein: $1.95 \pm 0.24 \mathrm{~g} / \mathrm{kg} /$ day; Carbohydrate: $8.49 \pm 1.15 \mathrm{~g} / \mathrm{kg} / \mathrm{day}$; Fat: $4.22 \pm 0.55 \mathrm{~g} /$ $\mathrm{kg} /$ day. The EGG preprandial study period recorded and analyzed among these preterm neonates were (Mean \pm SEM) $64.5 \pm 2.9$ and $43.9 \pm 3.4$ minutes, respectively. The EGG postprandial study period recorded and analyzed in this group was (Mean \pm SEM) $58.7 \pm 2.6$ minutes and $38.6 \pm 2.9$ minutes, respectively. The time that the EGG study was performed in this group was (Mean \pm SEM) $4.4 \pm 0.6$ days of life.

Group III of subjects was composed of 15 clinically stable premature neonates (28-31 weeks). The Apgar scores at one and at five minutes of life were (Mean \pm SEM) $6.8 \pm 0.5$ and $8.2 \pm 0.2$, respectively. The gestational ages at birth and at the time of the study were (Mean \pm SEM) 29.6 \pm 0.3 weeks (range: $281 / 7$ to 31 weeks) and $30.8 \pm 0.3$ weeks (range: 29 to $323 / 7$ weeks), respectively. The weight at birth and at the time of the study were (Mean \pm SEM) $1.3 \pm 0.07 \mathrm{~kg}$ (range: 0.93 to $1.70 \mathrm{~kg}$ ) and $1.2 \pm 0.08 \mathrm{~kg}$ (range: 0.79 to $1.83 \mathrm{~kg}$ ), respectively. Seven neonates $(46.7 \%)$ were White and 8 $(53.3 \%)$ were Afro-Americans. Seven neonates $(46.7 \%)$ were male and 8 $(53.3 \%)$ were female. All 15 premature neonates were appropriate for gestational age. Twelve neonates $(80 \%)$ were on formula (Enfamil Premature care-20, or Similac Special care-20, or Similac Neocare-22) and three (20\%) were on breastfeeding. Based on the milk volume that could be measured the volume, the amount of calories, protein, carbohydrate, and fat per kilogram body weight per day among these preterm neonates was (Mean \pm SEM): Volume: $87.5 \pm 11.07 \mathrm{ml} /$ $\mathrm{kg} / \mathrm{day}$; Calories: $60.55 \pm 8.6 \mathrm{kcal} / \mathrm{kg} /$ day; Protein: $1.57 \pm 0.3 \mathrm{~g} / \mathrm{kg} /$ day; Carbohydrate: $6.55 \pm 0.9 \mathrm{~g} / \mathrm{kg} / \mathrm{day}$; Fat: $3.26 \pm 0.5 \mathrm{~g} / \mathrm{kg} /$ day.The EGG preprandial study period recorded and analyzed among these preterm neonates were $(\mathrm{Mean} \pm \mathrm{SEM}$ ) 58.7 \pm 2.6 minutes and $38.5 \pm 3.2$ minutes, respectively. The EGG postprandial study period recorded and analyzed in this group were (Mean \pm SEM) $58.4 \pm 1.5$ minutes and $38.9 \pm 2.7$ minutes, respectively. The time that the EGG study was performed in this group was (Mean \pm SEM) $8.7 \pm 0.9$ days of life.

\section{Effect of gestational age on the gastric myoelectrical activity}

\section{Percentage of Normogastria, Bradygastria, and Tachygastria}

Normogastria (or normal gastric slow wave or normal 2.4 to $3.7 \mathrm{cpm}$ gastric myoelectrical activity) as well as gastric myoelectrical dysrhythmias (bradygastria and tachygastria) were recorded in all neonates in groups I, II, and III (Table 1).

The percentages of normogastria, pre-and postprandially were: Group I: (Mean \pm SEM) $47.4 \pm 5.5 \%$ (range: 7.7 to $100 \%$ ) and $53.4 \pm 3.8 \%$ (range: 19.4 to $76.1 \%)$; Group II: (Mean \pm SEM) $41.9 \pm 2.9 \%$ (range: 26.7 to $67.5 \%$ ) and $52.7 \pm 4.9 \%$ (range: 17.4 to $90.2 \%$ ); and Group III: (Mean \pm SEM) $43.8 \pm 3.3 \%$ (range: 16.7 to $62.8 \%$ ) and $51.8 \pm 4.8 \%$ (range: 22.7 to $78.9 \%$ )

As shown in table 1 there were no significant differences in the percentage of normogastria among the three groups of neonates during the preprandial $(\mathrm{p}=0.6)$ and postprandial $(\mathrm{p}=0.9)$ periods. Furthermore, there were also no significant differences in the normogastria difference score (postprandial values minus preprandial values) among the three groups of patients $(p=0.8)$. The results of this study showed a percentage of normogastria activity lower than $70 \%$ during the pre-and postprandial periods for pre-

Table 1 - Percentage of Bradygastria, Normogastria, and Tachygastria in full term and premature neonates during their first two weeks of life (Mean \pm SEM).

\begin{tabular}{|c|c|c|c|c|c|c|}
\hline \multirow[t]{2}{*}{ Subjects } & \multicolumn{2}{|c|}{$\%$ of Bradygastria } & \multicolumn{2}{|c|}{$\%$ of Normogastria } & \multicolumn{2}{|c|}{$\%$ of Tachygastria } \\
\hline & preprandial & postprandial & preprandial & postprandial & preprandial & postprandial \\
\hline Group I $(\mathrm{N}=15)$ full term infants $)$ & $28.8 \pm 4.9$ & $22.8 \pm 4.0$ & $47.4 \pm 5.5$ & $53.4 \pm 3.8$ & $23.7 \pm 5.9$ & $23.7 \pm 3.3$ \\
\hline Group II $(\mathrm{N}=15)>32$ and $<37$ wk & $27.3 \pm 3.8$ & $17.9 \pm 2.6$ & $41.9 \pm 2.9$ & $52.7 \pm 4.9$ & $30.4 \pm 2.9$ & $29.5 \pm 4.5$ \\
\hline Group III $(\mathrm{N}=15)>28$ and $<32$ wk & $28.4 \pm 3.5$ & $20.7 \pm 2.8$ & $43.8 \pm 3.3$ & $51.8 \pm 4.8$ & $27.8 \pm 2.9$ & $27.5 \pm 4.7$ \\
\hline$($ Mean \pm SEM $)$ among groups & $28.2 \pm 2.3$ & $20.5 \pm 1.9$ & $0.4 \pm 2.3$ & $52.7 \pm 2.6$ & $27.3 \pm 2.4$ & $26.9 \pm 2.4$ \\
\hline $\mathrm{P}$ value among groups & 0.9 & 0.6 & 0.6 & 0.9 & 0.5 & 0.6 \\
\hline
\end{tabular}


mature and full term neonates. Other investigators ${ }^{36,38}$ have also demonstrated this finding.

Gastric myoelectrical dysrhythmias (bradygastria and tachygastria) were recorded in all neonates as well. The percentage of time in which bradygastria and tachygastria were present among these neonates also varied widely. The percentages of bradygastria and tachigastria, pre-and postprandially, were respectively : Group I: percentage of bradygastria: (Mean \pm SEM) $28.8 \pm 4.9 \%$ (range: 0 to $56.3 \%$ ) and $22.8 \pm 4.0 \%$ (range: 0 to $54.8 \%$ ), percentage of tachygastria: (Mean \pm SEM) $23.7 \pm 5.9 \%$ (range: 0 to $92.3 \%$ ) and $23.7 \pm 3.3 \%$ (range: 0 to $.7 \%$ ): Group II: percentage of bradygastria: (Mean \pm SEM) $27.3 \pm 3.8 \%$ (range: 4.1 to $57.1 \%$ ) and $17.9 \pm 2.6 \%$ (range: 2.4 to $37.5 \%$ ), percentage of tachygastria: (Mean \pm SEM) $30.4 \pm 3.4 \%$ (range: 10.0 to $57.1 \%$ ) and $29.5 \pm 4.5 \%$ (range: 4.9 to $65.2 \%$ ); and Group III: percentage of bradygastria: (Mean \pm SEM) $28.4 \pm 3.5 \%$ (range: 11.4 to $56.9 \%$ ) and $20.7 \pm 2.8 \%$ (range: 7.5 to $41.7 \%$ ), percentage of tachygastria: (Mean \pm SEM) $27.8 \pm 2.8 \%$ (range: 10.3 to $58.3 \%$ ) and $27.5 \pm 4.7 \%$ (range: 2.8 to $61.5 \%)$.

This study has also demonstrated that no significant differences were observed in the percentage of bradygastria (preprandial $\mathrm{p}=0.9$, postprandial $\mathrm{p}=0.6$ ) and tachygastria (preprandial $\mathrm{p}=0.5$, postprandial $\mathrm{P}=0.6$ ) among the three groups of neonates (Table 1). There were also no significant differences among the three groups of neonates regarding to the bradygastria $(\mathrm{P}=0.9)$ and tachygastria difference scores $(\mathrm{P}=0.9)$.

In this study as well as in the studies by Liang ${ }^{36}$ and by $\mathrm{Chen}^{38}$ enteral feedings (milk) did not induce significant changes in the percentage of normogastria, bradygastria, and tachygastria during the postprandial period. Nevertheless, changes in these parameters were noted individually.

\section{EGG Dominant Frequency (cpm)}

All neonates in the three groups studied had the mean values of the EGG dominant frequency predominantly within the normogastria range (2.4 to $3.7-\mathrm{cpm}$ ), during the pre-and postprandial periods. The mean values of the EGG dominant frequency for groups I, II, and III are presented in the table 2. As shown in table 2, no significant differences were observed in the EGG dominant frequency among neonates in groups I, II, and III during the preprandial $(\mathrm{p}=0.3)$ and postprandial $(\mathrm{p}=0.2)$ periods. There were also no significant differences in the EGG dominant frequency difference score $(p=0.9)$ among the three groups.

\section{Relative Change of the EGG \\ Dominant Power}

Despite EGG dominant power has varied widely among the neonates in the three groups, there were no significant differences in the relative change of the EGG dominant power among the groups: Group I and Group II ( $\mathrm{p}=0.5)$; Group I and Group III ( $\mathrm{p}=0.6$ ), and Group II and Group III ( $\mathrm{p}=0.4)$ (Table 3).

Table 2 - Electrogastrography dominant frequency $(\mathrm{cpm})$ in full term and premature neonates during their first two weeks of life (Mean \pm SEM).

\begin{tabular}{lcc}
\hline Subjects & $\begin{array}{c}\text { Preprandial } \\
\text { Electrogastrography } \\
\text { dominant } \\
\text { frequency }(\mathrm{cpm})\end{array}$ & $\begin{array}{c}\text { Postprandial } \\
\text { Electrogastrography } \\
\text { dominant } \\
\text { frequency }(\mathrm{cpm})\end{array}$ \\
\hline Group I $(\mathrm{N}=15$, full term infants) & $2.89 \pm 0.2$ & $2.76 \pm 0.2$ \\
Group II $(\mathrm{N}=15,>32$ and $<37 \mathrm{wk})$ & $2.48 \pm 0.2$ & $3.21 \pm 0.2$ \\
Group III $(\mathrm{N}=15,>28$ and $<32 \mathrm{wk})$ & $2.59 \pm 0.2$ & $2.96 \pm 0.2$ \\
(Mean \pm SEM) among groups & $2.65 \pm 0.1$ & $2.98 \pm 0.2$ \\
P value Among groups & 0.3 & 0.2 \\
\hline
\end{tabular}

Table 3 - Relative changes of Electrogastrography dominant power in full term and premature neonates during their first two weeks of life (Mean \pm SEM).

\begin{tabular}{lc}
\hline Subjects & $\begin{array}{c}\text { Relative changes of Electrogastrography } \\
\text { dominant power }\end{array}$ \\
\hline Group I $\quad(\mathrm{N}=15$, full term infants $)$ & $1.4 \pm 0.4$ \\
Group II $\quad(\mathrm{N}=15,>32$ and $<37 \mathrm{wk})$ & $2.4 \pm 1.4$ \\
Group III $\quad(\mathrm{N}=15,>28$ and $<32 \mathrm{wk})$ & $1.2 \pm 0.2$ \\
\hline
\end{tabular}

\section{DISCUSSION}

The Electrogastrography techin 45 neonates of different gestational ages. This study has demonstrated that EGG is a safe procedure to be performed in neonates since none of the potential risks involved in this procedure occurred. Those included skin irritation caused by placement of the electrodes on the abdominal skin and electric shock related to the use of electric equipment.

Beside being a safe procedure, the EGG technique has further characteristics which make it an attractive clinical tool to study gastric myoelectrical activity in neonates as follow: the EGG is a non-invasive technique that can be repeated on many occasions both before and after possible gastric stimuli such as different feeding regimens or use of prokinetic agents. Furthermore, it can be used to assess the gastric myoelectrical activity during systemic diseases; and the EGG device shape of a "walkman" which can be placed at bedside and, therefore, the nique (EGG) was recorded successfully is a portable machine of the size and 
neonate does not have to be replaced out of his bed to undergo the procedure, which could contribute to deteriorate his clinical status.

The relatively poor quality of the EGG signal, however, makes it imperative that the acquisition of the EGG signal in neonates be even more accurate. The EGG signal is described as being of poor quality because it is a combination of the gastric signal and noises ${ }^{29}$. Noises are composed of respiratory and motion artifacts, the electrical activity of the heart and the electrical activity of the small intestine. Among these noises motion artifacts are the most important to be considered in performing EGG studies in neonates. Motion artifacts can disturb the EGG signal for several reasons ${ }^{49}$ : they may be strong and completely obscure the myoelectrical signal of the stomach; they have a broad-band spectrum and their frequencies may overlap with that of the gastric myoelectrical activity making it difficult to separate them even with the use of spectral analysis; and no effective methods are available for the cancellation of motion artifacts as the EGG signal is being recorded. In this study some measures were adopted in order to obtain satisfactory EGG recordings in neonates. The measures that seemed to be effectively were: to swaddle and not manipulate the neonate during the whole study period; to study the neonate in a silent room with little or no light or auditory stimulation. Light and auditory stimulation may keep the infant awake, may promote crying, or even trigger the Moro reflex, thus, contributing to an unsatisfactory acquisition of the EGG signal, to change the infant's dippers before the EGG study starts and after the neonate is fed. The EGG meal period, i.e., between the pre-and postprandial periods, is not submitted to quantitative analysis, although the gastric myoelectrical activity is continuously recorded. There- fore, this period of the study is the appropriate time for manipulating the neonate, if it is necessary; and to record the EGG signal for at least 1hour during the pre-and postprandial periods to obtain around 30 minutes of clean data after EGG segments contaminated by noises are deleted. Despite the measures to avoid motion artifacts, it was impossible to have an EGG recording absolutely free of artifacts. Therefore, these artifacts had to be deleted visually before quantitative analysis of the EGG data was performed.

The Eletrogastrogram for EGG analysis software (Synectics MedicalGastrosoft, version 6.30) was used to perform the quantitative analysis of the EGG signal. This software is based on the "Running Spectrum Analysis" which results in overlapping the analysis of $75 \%$ of the data available. Due to the overlapping, ignoring a segment of data, ends up affecting the frequency analysis of data that starts about five minutes before and ends about five minutes after the ignored segment ${ }^{45}$. This results in loss of clean EGG data as well. For these reasons the EGG study period analyzed was shorter when compared to the total EGG study period recorded during the pre-and postprandial periods in all three groups of neonates. This is the main reason for performing "prolonged" EGG studies in neonate.

Regarding to the EGG parameters analyzed, this study has shown that normal gastric myoelectrical activity as well as gastric myoelectrical dysrhythmias (bradygastria and tachygastria) are similarly present after birth in premature and full term neonates during the pre-and postprandial periods. This finding suggests that the development of gastric myoelectrical activity is not strongly associated with the gestational age at birth. The similar EGG patterns between premature and full term neonates during the pre- and postprandial periods have also been demonstrated by other investigators $^{34,38}$. Furthermore, manometric studies performed in neonates ${ }^{4,9}$ have demonstrated no significant differences in the gastric activity between premature and full term neonates during their first weeks of life.

It is interesting to note that the dominant frequency of the EGG signal among the three study groups was within the normogastria range (2.4-3.7 cpm), however, the percentage of time in which normal gastric myoelectrical activity was recorded in premature and full term neonates was lower than those described in the literature for neonates older than 2 months, children, and adults ${ }^{38,46,48,50-52}$. Data from the literature has demonstrated a percentage of normal gastric slow waves greater than $70 \%$ in older children and neonates. Although the percentage of normal gastric slow wave varied widely among all infants described in this study, it seems reasonable to consider 30 to $60 \%$ of the percentage of normal gastric myoelectrical activity as an acceptable range for healthy premature (> 28 weeks of gestation) and full term neonates during their first two weeks of life.

Another interesting finding in this study was that the percentages of bradygastria and tachygastria in premature and full term neonates were higher than those described in the literature for healthy adults ${ }^{48,50}$. In fact, this finding was expected since these parameters are inter-dependent and the neonates that were studied had low percentages of normogastria. Although increases in the percentage of bradygastria ${ }^{39,53-64}$ and tachygastria ${ }^{53,55,57,59-75}$ in adults have been associated with a wide range of diseases and disorders associated with nausea and vomiting, and also with gastric hypomotility, its occurrence in neonates suggests a normal developmental process. 
Among all the EGG parameters described in this study, the power of the EGG signal is the one associated with major controversies in the literature. This is due to the fact that the power of the EGG signal is related to many factors ${ }^{45}$. For that reason it has been speculated that the absolute values of the EGG dominant power may not provide useful information ${ }^{46,76}$ and only relative changes of the EGG dominant power would have clinical significance $^{44,46,76,77}$. The most important factors known to affect the power of the EGG signal are $^{46}$ : thickness of the abdominal wall of the subject; skin preparation (skin electrode impedance); position of the electrodes (motion artifacts); distance between polar electrodes; characteristic of the recording equipment; the propagation velocity of the gastric slow wave (which varies from person to person); the method of spectral analysis and type of feeding. Among the factors known to interfere with the amplitude (or power) of the EGG signal, motion artifacts were the most evident in this study. Despite the fact that all infants were swaddled during the entire study period, slight movements of the arms and legs still occurred. Even the slightest movements were enough to disturb the power of the EGG signal. Besides motion artifacts, there were no significant differences in the relative change of the EGG dominant power among the three groups.
While motion artifacts had a definitive interference on the power of the EGG signal, the interference caused by the type of feeding was less evident. Despite a similar volume and nutritional composition of the milks ingested by the neonates, there were no consistent responses of the EGG power to enteral feedings. Interestingly, controversial findings in adults have also been reported regarding the effect of milk on the EGG power. Some investigators reported that whole milk and yogurt meals increase the power of the EGG signal ${ }^{54,78}$, whereas others ${ }^{79}$ have reported a decrease in the power of the EGG signal after ingestion of a test meal of milk with a fat content of $10 \%$.

In conclusion, this study demonstrates that gastric myoelectrical activity can be successfully recorded in clinically stable premature and full term neonates by means of EGG. This study also demonstrates that the EGG patterns are similar between premature and full term neonates, pre-and postprandially, during their first two weeks of life. Furthermore, the volume and the type of feeding as well as the day of life that the EGG analysis were performed in this study did not seem to interfere with the gastric myoelectrical activity. However, as the objective of this study was not to analyse the influence of volume and composition of milk on the gastric myoelectrical actvity, further studies addressing these issues are necessary. Lastly, the results of this study indicate that the gastric myoelectrical activity in premature and full term neonates is immature, as compared to that described for older neonates, children and adults. The EGG findings that suggest an immaturity of the gastric myoelectrical activity in neonates are: low percentage of time in which the EGG dominant frequency is within the normal 2.4 to 3.7cpm gastric myoelectrical activity range, lack of trend of the EGG power in response to enteral feedings, considerably unstable EGG dominant power during the pre and postprandial periods, and no significant differences between pre-and postprandial periods regarding to all EGG parameters analyzed in this study. The EGG patterns described in this study may provide a physiological basis to explain the immaturity of gastrointestinal motor function in neonates. The normative values described by this study may be relevant in the use of Electrogastrography as a clinical tool for assessing gastrointestinal motility disorders in neonates.

\section{ACKNOWLEDGMENTS}

This study was supported in part by CAPES Foundation - grant: BEX1103/98-99, São Paulo, Brazil.

\section{RESUMO}

PRECIOSO AR e col. - Atividade mioelétrica gástrica em recémnascidos de diferentes idades gestacionais através da eletrogastrografia. Rev. Hosp. Clín. Fac. Med. S. Paulo 58(2):81-90, 2002.

OBJETIVO: Descrever os padrões da atividade mioelétrica gástrica, durante os períodos pré e pós-prandial, em recém-nascidos de diferentes idades gestacionais e clinicamente estáveis, durante as duas primeiras semanas de vida, através da Eletrogastrografia.

PACIENTES E MÉTODOS: A
Eletrogastrografia foi realizada em 45 recém-nascidos, de diferentes idades gestacionais e clinicamente estáveis (grupo I: 15 recém-nascidos $>37$ semanas, grupo II: 15 recém-nascidos de 32-37 semanas; Grupo III: 15 recémnascidos de 28-31 semanas) que estavam recebendo dieta enteral de forma 
intermitente durante as duas primeiras semanas de vida. Registros eletrogastrográficos foram realizados por 1 hora antes e por 1 hora após terem sido alimentados. O sinal eletrogastrográfico foi obtido com o aparelho portátil "MicroDigitrapper Eletrogastrografia recording device" e após eliminação de artefatos relacionados a movimentação corporal, o traçado eletrogastrográfico remanescente foi submetido à analise quantitativa baseada no método "Running Spectrum Analysis".

RESULTADOS: As porcentagens de normogastria, pré e pós-prandial, foram maiores que as porcentagens de arritmias gástricas nos três grupos estudados. Além disso, todos os recémnascidos apresentaram freqüência dominante do sinal eletrogastrográfico dentro do intervalo correspondente a normogastria, em ambos os períodos analisados. Não houve diferença estatisticamente significante nas mudanças relativas da amplitude dominante do sinal eletrogastrográfico entre os três grupos estudados.

CONCLUSÃO: Este estudo demonstrou que recém-nascidos prematuros e de termo apresentam padrões eletrogastrográficos semelhantes durante os períodos pré e pós-prandial. Os resultados deste estudo também demonstraram que a atividade mioelétrica gástrica em recém-nascidos prematuros e de termo é imatura quando comparada com a descrita para lactentes, crianças e adultos.

DESCRITORES: Eletrogastrografia. Atividade mioelétrica gástrica. Recém-nascidos. Diferentes idades gestacionais. Períodos pré e pósprandial.

\section{REFERENCES}

1. BERSETH CL - Minimal Enteral Feedings. Clin Perinatol 1995; 22: 195-205.

2. BERSETH CL - Gastrointestinal Motility in the Neonate. Clin Perinatol 1996; 23: 179-190.

3. BROUSSARD DL - Gastrointestinal Motility in the Neonate. Clin Perinatol 1995; 22: 37-50.

4. ITTMANN PI, AMARNATH R, BERSETH CL - Gestational Maturation of Antroduodenal Motor Activity in Preterm and Term Infants. Dig Dis Sci 1992; 37: 14-19.

5. BERSETH CL, ITTMANN PI - Antral and duodenal motor responses to duodenal feeding in preterm and term infants. $\mathbf{J}$ Pediatr Gastroenterol Nutr 1992; 14: 182-186.

6. BERSETH CL - Neonatal small intestinal motility: motor responses to feeding in term and preterm infants. J Pediatr 1990; 117:777-782.

7. TAWIL Y, BERSETH CL - Gestational and postnatal maturation of duodenal motor responses to intragastric feeding. J Pediatr 1996; 129:374-381.

8. DE VILLE KT, SHULMAN RJ, BERSETH CL - Slow infusion feeding enhances gastric emptying in preterm infants compared to bolus feeding (abstract). Clin Res 1993; 41: 787A.

9. TOMOMASA T, ITOH Z, KOIZUMI T et al. - Nonmigrating rhythmic activity in the stomach and duodenum of neonates. Biol Neonate 1985; 48: 1-9.

10. OMARI TI, RUDOLPH CD - Gastrointestinal Motility. In: POLIN RA, FOX WW, eds. Fetal and Neonatal Physiology. Philadelphia, Saunders, 1998. p. 1373-1383.

11. DUMONT C, RUDOLPH C - Development of Gastrointestinal Motility in the Infant and Child. Gastroenterology Clin N Am 1994; 23:655-671.
12. SIDEBOTTOM R, CURRAN JS, WILLIAMS PR, KANARET KS et al. - Effects of long-chain vs medium-chain triglycerides on gastric emptying time in premature infants. J Pediatr 1983; 102: $8-450$.

13. TOMOMASA T, HYMAN PE, ITOH K et al. - Gastrodudenal motility in neonates: Response to human milk compared with cow's milk formula. Pediatrics 1987; 80: 434-438.

14. HOUGHTON LA, READ NW, HEDDLE R et al. - Motor activity of the gastric antrum, pylorus and duodenum under fasted conditions and after a liquid meal. Gastroenterology 1988; 94: $1276-1284$.

15. BERSETH CL - Gestational evolution of small intestinal motility in preterm and term infants. J Pediatr 1989; 115: 646-651.

16. BISSET WM, WATT JB, RIVERS RP et al. - Ontogeny of fasting small intestinal motor activity in the human infant. Gut 1988; 29: 483-488.

17. CODE CF, MARLETT JÁ - The interdigestive myo-electric complexes of the stomach and small bowel of dogs. J Physiol 1975; 246: 289-309.

18. AMARANTH RP et al. - Posnatal maturation of small intestinal motility in preterm infants. J Gastroint Motil 1989; 1: 138142.

19. JADCHERLA SR, BERSETH CL - Cycling of plasma motilin and pancreatic polypeptide concentrations with migrating activity is blunted in term infants (abstract). Pediatr Res 1994; 35: $128 \mathrm{~A}$.

20. READ NW, AL-JANABI MN, EDWARDS CA et al. - Relationship between postprandial motor activity in the human small intestine and the gastrointestinal transit of food. Gastroenterology 1984; 86: 721-727. 
21. KERLIN P, PHILLIPS S - Variability of motility of the ileum and jejunum in healthy humans. Gastroenterology 1982; 82: $694-$ 700

22. ALVAREZ WC - The electrogastrogram and what it shows. Am J Physiol 1922; 78: 1116-1119.

23. CHEN JZ, MCCALLUM RW - Electrogastrography: measurement, analysis and prospective applications. Med Biol Eng Comput 1991; 29: 339-350.

24. ABELL TL, MALAGELADA JR - Electrogastrography: Current assessment and future perspectives. Dig Dis Sci 1988; 33: 982-992.

25. SMOUT AJPM, VAN DER SCHEE EJ, GRASHUIS JL - What is measured in electrogastrography? Dig Dis Sci 1980; 25: 179187

26. CHEN JZ, SCHIRMER BD, MCCALLUM RW - Serosal and cutaneous recordings of gastric myoelectrical activity in patients with gastroparesis. Am J Physiol 1994; 266: G90G98.

27. PFAFFENBACH B, ADAMEKI RJ, BARTHOLOMAUS C, WEGNER M. - Gastric Dysrhythmias and delayed gastric emptying in patients with functional dyspepsia. Dig Dis Sci 1997; 42: 2094-2099.

28. CHEN JZ, LIN Z, PAN J, MCCALLUM RW - Abnormal gastric myoelectrical activity and delayed gastric emptying in patients with symptoms suggestive of gastroparesis. Dig Dis Sci 1996; 41: $1538-1545$.

29. CHEN JZ, MCCALLUM RW - F.A.C.G. Clinical Applications of Electrogastrography. Am J Gastroenterol 1993; 88: 13241336.

30. ROTHSTEIN RD, ALAVI A, REYNOLDS JC Electrogastrography in patients with gastroparesis and effect of long-term cisapride. Dig Dis Sci 1993; 38: 1518-1524.

31. RIEZZO G, CUCCHIARA S, CHILOIRO M et al. - Gastric emptying and myoelectrical activity in children with nonulcer dyspepsia - effect of cisapride. Dig Dis Sci 1995; 40:14281434.

32. CHEN JDZ, PAN J, ORR WC - Role of sham feeding in postprandial changes of gastric myoelectrical activity. Dig. Dis. Sci 1996; 41: 1706-1712.

33. TOMOMASA T, MIYAZAKI M, NAKO $\mathrm{Y}$ et al. Electrogastrography in Neonates. J Perinatol 1994; XIV: 417421

34. KOCH KL, TRAN TN, STERN RM et al. - Gastric myoelectrical activity in premature and term infants. J Gastrointest Mot 1993; 5: 41-47.

35. MIHAILOFF J, KOCH KL, STIFTER C - Gastric myoelectrical activity in healthy infants: A cross-sectional study of 48 infants (abstract). Gastroenterology 1997; 112: 92A

36. LIANG J, CO E, ZHANG M et al. - Development of gastric slow waves in preterm infants measured by electrogastrography. Am J Physiol 1998; 274: G503-508.
37. ZACCHI P, KOLETZKO S, ENCK P et al. - Electrogastrography in term and preterm infants. J Pediatr Gastroenterol Nutr (abstract). 1993; 17: 474 (90).

38. CHEN JZ, CO E, LIANG J et al. - Patterns of gastric myoelectrical activity in human subjects of different ages. Am J Physiol 1997; 272: G1022-1027.

39. DEVANE SP, RAVELLI AM, BISSET WM et al. - Gastric antral dysrhythmias in children with chronic idiopathic intestinal pseudo-obstruction. Gut 1992; 33: 1477-1481.

40. CUCCHIARA S, RIEZZO S, MINELLA $\mathrm{R}$ et al. Electrogastrography in non-ulcer dyspepsia. Arch Dis Child 1992; 67: 613-617.

41. RAVELLI AM, MILLA PJ - Vomiting and gastroesophageal motor activity in children with disorders of the central nervous system. J Pediatr Gastroenterol Nutr 1998; 26: 56-63.

42. RAVELLI AM, HELPS BA, DEVANE SP et al. - Normal gastric antral myoelectrical activity in early onset anorexia nervosa. Arch Dis Child 1993 69: 342-346.

43. BALLARD JL, NOVAK KZ, DRVER MA - A simplified score for assessment of fetal maturation of newly born infants. J Pediatric 1979; 95: 769-774

44. SMOUTH AJPM, JEBBINK HJA, SAMSOM M - Acquisition and analysis of electrogastrographic data: The Dutch Experience. In: CHEN JDZ, MCCALLUM RW, eds. Electrogastrography principles and applications. New York, Raven Press, 1994. p.3-30.

45. ELECTROGASTROGRAM - Software Reference Manual, version 6.30. Synectics Medical-Gastrosoft, 1995. p.1-146.

46. CHEN JZ, MCCALLUM RW - Electrogastrographic parameters and their clinical significance. In: CHEN JDZ, MCCALLUM RW, eds. Electrogastrography principles and applications. New York, Raven Press, 1994. p. 45-73

47. KOCH KL, STERN RM - Electrogastrographic data acquisition and analysis. The Penn State experiences. In: CHEN JDZ, MCCALLUM RW, eds. Electrogastrography principles and applications. New York, Raven Press, 1994. p. 31-.

48. PARKMAN HP, HARRIS AD, MILLER MA et al. - Influence of age, gender, and menstrual cycle on the normal electrogastrogram. Am J Gastroenterol 1995; 91:127-133.

49. CHEN JZ, LIN Z, MCCALLUM RW - Toward ambulatory recording of electrogastrogram. In: CHEN JDZ, MCCALLUM RW, eds. Electrogastrography principles and applications. New York, Raven Press, 1994. p. 127-153.

50. PFAFFENBACH B, ADAMEK RJ, KUHN $\mathrm{K}$ et al. Electrogastrography in healthy subjects - Evaluation of normal values, influence of age and gender. Dig Dis Sci 1995; 40: 151450

51. LIN X, MELLOW MH, SOUTHMAYD L et al. - Impaired gastric myoelectrical activity in patients with chronic renal failure. Dig Dis Sci 1997; 42: 898-906.

52. CHEN JZ, MCCALLUM RW - Gastric slow wave abnormalities in patients with gastroparesis. Am J Gastroenterol 1992; 87: 477-482. 
Gastric myoelectrical activity in neonates of different gestational ages Precioso AR et al.

53. ABELL TL, MALAGELADA JR - Glucagon-evoked gastric dysrhythmias in humans shown by an improved electrogastrographic technique. Gastroenterology 1985; 88: 1932-1940.

54. HAMILTON JW, BELLAHSENE BE, REICHELDER M et al. Human Electrogastrograms. Comparasion of surface and mucosal recordings. Dig Dis Sci 1986; 31: 33-39.

55. KOCH KL, STERN RM, STEWART WR, et al. - Gastric emptying and gastric myoelectrical activity in patients with diabetic gastroparesis: effect of long-term domperidone treatment. Am J Gastroenterol 1989; 84: 1069-1075.

56. CUCCHIARA S, MINELLA R, RIEZZO G et al. - Reversal of gastric electrical dysrhythmias by cisapride in children with functional dyspepsia. Report of three cases. Dig Dis Sci 1992; 37: 1136-1140.

57. HASLER WL, SOUDAH HC, DULAI G et al. - Mediation of hyperglycemia-evoked gastric slow wave dysrhythmias by endogenous prostaglandins. Gastroenterology 1995; 108: 727-736.

58. BORTOLOTTI M, SARTI P, BARARA L et al. - Gastric myoelectrical activity in patients with chronic idiopathic gastroparesis. J Gastrointest Motil 1990; 2: 104-108.

59. LIBERSK SM, KOCH KL, ATNIP RG et al. - Ischemic gastroparesis: resolution after revascularization. Gastroenterology 1990; 99: 252-257.

60. GELDOF H, VAN DER SCHEE EJ, VAN BLANKENSTEIN MG - Electrogastrographic study of gastric myoelectrical activity in patients with unexplained nausea and vomiting. Gut 1986; 27: 799-808.

61. KIM CH, ZINSMEISTER AR, MALAGELADA JR - Mechanisms of cannine gastric dysrhythmia. Gastroenterology 1987; 92: 993-999.

62. YOU CH, CHEY WY - Study of electromechanical activity of the stomach in humans and in dogs with particular attention to tachygastria. Gastroenterology 1984; 86: 1460-1468.

63. KOCH KL, MEDINA M, BINGAMAN S et al. - Gastric dysrhythmias and visceral sensations in patients with functinal dyspepsia (abstract). Gastroenterology 1992; 102: 469.

64. KOCH KL, XU L, BINGAMAN S et al. - Effects of ondansetron on morphine-induced nausea, vasopressin and gastric myoelectrical activity in healthy humans. Gastroenterology (abstract). 1993; 104: 535.

65. KOCH KL, STERN RM, VASEY MW et al. - Gastric dysrhythmias and nausea of pregnancy. Dig Dis Sci 1990; 35: 961-968.

66. KOCH KL, STERN RM - Nausea and vomiting and gastric dysrhythmias. In: CHEN JDZ, MCCALLUM RW, eds. Electrogastrography principles and applications. New York, Raven Press, 1994. p. 309-330.
67. YOU CH, CHEY WY, LEE KY et al. - Gastric and small intestinal myoelectrical activity dysrhythmias associated with chronic intractable nausea and vomiting. Ann Intern Med 1981; 95: $9-451$.

68. JEBBINK RJA, SAMSOM M, BRUIJS PP et al. - Hyperglycemia induces abnormalities of gastric myoelectrical activity in patients with type I diabetes mellitus. Gastroenterology 1994; 107: 1390-1397.

69. WALSH JW, HASLER WL, NUGENT CE et al. - Progesterone and estrogen are potential mediators of gastric slow wave dysrhythmias in nausea of pregnancy. Am J Physiol 1996; 270: G506-G514.

70. RIEZZO G, PEZZOLlA F, DARCONZA G et al. - Gastric myoelectrical activity in the first trimester of pregnancy: a cutaneous electrogastrography study. Am J Gastroenterol 1992; 87: 702-707.

71. ABELL TL - Nausea and vomiting of pregnancy and the electrogastrogram: old disease, new technology. Am J Gastroenterol 1992; 87: 689-691.

72. YOU CH, LEE KY, CHEY WY et al. - Electrogastrographic study of patients with unexplained nausea, bloating and vomiting. Gastroenterology 1980; 79: 311-314.

73. ABELL TL, MALAGELADA JR, LUCAS AR et al. - Gastric electromechanical and neurohormonal function in anorexia nervosa. Gastroenterology 1987; 93: 958-965.

74. STERN RM, KOCH KL, STEWART WR et al. - Spectral analyis of tachygastria recorded during motion sickness. Gastroenterology 1987; 92: 92-97.

75. KOHAGEN RK, KIM MS, MCDONNELL WM et al. - Nicotine effects on prostraglandin-dependent gastric slow wave rhythmicity and antral motility in nonsmokers and smokers. Gastroenterology 1996; 11: 110-113.

76. LIANG J, CHEN JZ - What can be measured from surface electrogastrography. Computer simulations. Dig Dis Sci 1997; 42:1331-1343.

77. CHEN JZ, RICHARDS RD, MCCALLUM RW - Identification of gastric contractions from the cutaneous electrogastrogram. Am J Gastroenterol 1994; 89: 79-85.

78. GELDOF H, VAN DER SCHEE EJ, SMOUT AJPM et al. Myoelectrical activity of the stomach in gastric ulcer patients: An electrogastrographic study. J Gastrointest Mot 1989; 1: 122-130.

79. CHEN JZ, MCCALLUM RW - Effect of milk on myoelectrical activity of the stomach - an electrogastrographic study. Med Biol Eng Comp 1992; 30:564-567. 